\title{
EDITORIAL
}

\section{Being Whole}

Just because I'm losing, doesn't mean I'm Lost. . . Just because I'm hurting, doesn't mean I'm Hurt -Chris Martin (2008)

As some of you may know, one of my roles within the Department of Psychiatry and Behavioral Sciences at Memorial Sloan Kettering Cancer Center is to serve as the Director of our Psychotherapy Laboratory. It's within this Laboratory that my colleagues and I developed Meaning Centered Psychotherapy. It's also within this Laboratory that we have developed unique and novel interventions for fear of breast cancer recurrence, meaning centered grief therapy, reduction of psychological distress in caregivers, posttraumatic stress disorder in bone marrow transplantation, distress in older cancer patients, and a variety of studies aimed at existential issues such as dignity, demoralization, desire for hastened death, hopelessness, and spiritual well-being. Our Laboratory meetings often take the form of "think tank" sessions in which we explore and try to dissect the meaning and components of existential concerns or constructs related to despair in the advanced cancer setting. Topics we've explored included existential isolation, existential guilt, and the inevitability of death, all subjects of recent editorials in Palliative \& Supportive Care.

Over the past month, we've been struggling with the concepts of "being whole" and the sense that one has lived a "coherent life." The process usually starts with me asking a question such as, "What do we mean when we say that a goal of palliative care is to help a patient bring some sense of coherent meaning to their lives as part of end of life task completion? We always say it; we keep repeating it in our lectures and with patients, but what are we talking about?" (Readers, please note that "coherence" will be the subject of a future editorial.) These past two weeks we've been struggling with the idea of "being whole." What do we mean when we urge patients to try to live life carefully, remaining upright and whole? (Breitbart, 2007). In particular, what are we truly referring to by this concept of being whole?

\section{BEING WHOLE: ALL OF ME, COMPLETE, INTACT}

There are a number of conceptualizations or definitions of the word "whole." Most definitions in dictionaries refer to the idea of the entire amount, or the complete totality of something, missing no part, element, or member. In a superficial sense, it's analogous to the night you ordered pizza to be delivered and you couldn't believe you ate the "whole" pie before the rest of your family arrived home. But we're not dealing with the superficial here. We're dealing with "being" whole; the existential question of the nature of being and that each of us is both physically and existentially a human being.

This concept of being physically and existentially whole reminds me of an ethics consult I was recently involved with in the hospital. The patient was a 17year-old adolescent with an aggressive osteogenic sarcoma that originated in his left leg but had in fact spread as well. The pediatric oncologists felt that the situation was extremely dire and that the only chance of prolonging this young man's life was to do a radical amputation of the leg and the pelvis and hip. Even with such surgery, the prognosis was still very grim. To make matters even more complex, this young man had been brought to our institution by a charitable foundation serving poor families from Greece. This young man only spoke Greek, as did his parents. His father was a goat shepherd, with no formal education, and the family lived in the Greek mountains. The parents were desperate to save or prolong the life of their son and were ready to agree to any treatment, no matter how radical. The son, however, refused to undergo an amputation. Because the 17-year-old was a minor, the parents were in fact the legal decision-makers; however, traditionally the "assent" of the minor is required, especially at an age so close to the legal age for consent.

I had extensive discussions with the treating team, the parents, and the 17-year-old patient. My goal was to try to find a consensus amongst all the parties on an appropriate treatment plan. The most compelling and transformational exchange came in 
a discussion between me, the young man, and his parents. This 17 -year-old young man was very bright and very aware of the nature of his illness, his poor prognosis, as well as the risks and benefits of treatment. But ultimately it was the following remarks to his beloved father and mother that brought a resolution to this desperate situation. He held back his tears as he spoke to his father and said, "I know that I will die, Father. I can accept this fact, this fate. I do not want to die young. I do not want to die before I have fallen in love, and had the experience of someone I love fall in love with me. I know you love me and please know how much I love you. And so, if you love me, please understand what I have to say, and what is so important to me about my life and how I die. Father, when I am buried in our family plot on the mountainside in Greece, I need to be buried with all my limbs intact; with my body whole. Dying and being buried as a whole body, as a whole being is a wish and a hope that allows me to die with a sense of peace, and with a sense of dignity." His parents understood this completely and agreed to not force their son to go through this surgery. This young man never left the hospital. He died of his disease approximately 3 weeks after this discussion. He was buried with all his limbs, his body intact; he died and was buried whole.

But what does it mean to be existentially whole? One aspect of this may be the concept that in all that I am and all that I do, I represent the entirety of who I am, authentically and completely. It is the notion of being truly authentic. Not wearing a mask or playing a role based on external expectations. If I am to be substantial, striving for significance in the world, then I should expect to have both admirers as well as critics. It is the notion that "If I don't have some people who actually dislike me, I'm probably not doing something of importance." Carl Jung (1962) wrote, "How can I be substantial if I do not cast a shadow? I must have a dark side also if I am to be whole." In his poem Odes, Fernando Pessoa (1955) writes "To be great, be whole; Exclude nothing, exaggerate nothing that is not you. Be whole in everything. Put all you are into the smallest thing you do." This existential aspect of "being whole" suggests that if one strives to live life fully and authentically, then the likelihood of experiencing existential guilt is diminished. Relieving or minimizing existential guilt may diminish death anxiety, regret and promote a sense of "being whole."

\section{BEING WHOLE: HEALING AND CONNECTION}

We are all broken. We are all imperfect. We are all mortal. We all experience loss, limitations, uncertainty. Death is the ultimate limitation and our mortality is our ultimate fragility and imperfection. Our imperfection teaches us empathy; to be capable of love. And our imperfection is what makes it possible for others to love us, because no one can love a perfect human being (we don't exist). Our imperfection is the gift that allows us to love and be loved in return. The essence of the human experience is connection. Connection to ourselves, and to each other, through love and care. Connection to the continuum of time and legacy (the past, present, and future), and finally the connection to something greater than ourselves (transcendence: connecting to nature, love, beauty, compassion, perhaps some concept of a creator or God). It is when we are disconnected from those we love and who/what we care about that we experience the despair of no longer "being whole." It is through reestablishing these connections, and ultimately through transcendence and connection with something greater than ourselves that we can reexperience "being whole." Just because I'm hurting, doesn't mean I am Hurt; doesn't mean I can't reexperience "Being Whole."

\section{REFERENCES}

Breitbart, W. (2007). Upright and whole: an approach to suffering in the face of death. Palliative \& Supportive Care, 5(4):347-349.

Jung, C.G. \& Jaffe, A. Memories, Dreams, Reflections. London: Collins, 1962.

Martin, C. (2008). "Lost." Viva La Vida or Death and All His Friends (CD). Parlophone Records.

Pessoa, F. (1955). Odes. Poetry, 87(1):26-27.

WILLIAM BREITBART, M.D.

Editor-in-Chief, Palliative \& Supportive Care Chairman, Jimmie C. Holland Chair in Psychiatric Oncology Department of Psychiatry and Behavioral Sciences Memorial Sloan-Kettering Cancer Center 641 Lexington Avenue, 7thFloor New York, New York 10022, USA Email: Breitbaw@mskcc.org 